\title{
Physiological versus viscosity-induced effects of water temperature on the swimming and sinking velocity of larvae of the serpulid polychaete Galeolaria caespitosa
}

\author{
Toby F. Bolton*, Jon. N. Havenhand
}

School of Biological Sciences, The Flinders University of South Australia, GPO Box 2100, Adelaide, South Australia 5001, Australia

\begin{abstract}
Water viscosity is inversely related to water temperature. Because marine invertebrate larvae generally operate in a hydrodynamic environment dominated by viscous forces (i.e. Reynolds numbers $<1$, temperature-induced changes in water viscosity may exert profound influence on the swimming and sinking velocity of larvae. Whilst the physiological effects of water temperature on larval locomotion have received considerable experimental investigation, the influence of temperatureinduced changes in water viscosity has received little attention. We investigated the relative physiological and viscosity-induced effects of water temperature at 25 and $15^{\circ} \mathrm{C}$ on the swimming and sinking velocity of larvae of the serpulid polychaete Galeolaria caespitosa (L.). Larvae of this species undergo considerable growth and development during their planktonic period such that the Reynolds number of the larval body (trochosphere) increases from 0.19 at hatching to 1.11 at $120 \mathrm{~h}$ post-hatching. Consequently we suggest that inertial forces may exert an influence on swimming at the later stages of larval development and therefore the influence of viscosity may change over the course of larval development. We also suggest that a temperature-induced increase in water viscosity will reduce the sinking velocity of larvae and may reduce the energy expenditure required to maintain location in the water column. Our results indicate that both physiological and viscosity components of water temperature influence the swimming velocity of $G$. caespitosa larvae. However, the influence of water viscosity did not change significantly over the course of larval development. The sinking velocity of $G$. caespitosa larvae was reduced with a temperature-induced increase in water viscosity. The reduction in sinking velocity of the larvae was proportional to the increase in water viscosity. We estimated and compared the metabolic costs of swimming to counteract sinking at 25 and $15^{\circ} \mathrm{C}$ by estimating $Q_{10}$ values from the metabolic effects of temperature on swimming velocity. We suggest that the metabolic costs of swimming to counteract sinking in $G$. caespitosa larvae are similar at 25 and $15^{\circ} \mathrm{C}$, but that the metabolic costs of swimming are slightly higher at $15^{\circ} \mathrm{C}$.
\end{abstract}

KEY WORDS: Larvae $\cdot$ Trochophore $\cdot$ Physiological $\cdot$ Viscosity $\cdot$ Swimming $\cdot$ Sinking $\cdot$ Velocity

\section{INTRODUCTION}

Ambient temperature has a profound influence on ectotherm physiology. The available literature indicates that marine invertebrate larvae are no exception to this rule. Ambient temperature influences both the metabolic rate of larvae (and hence locomotory rate)

-E-mail: bitfb@flinders.edu.au (e.g. Hirche 1984, Robinson \& Williams 1993) and cellular processes such as the efficiency of enzyme function (e.g. Clarke 1983), membrane fluidity (e.g. Hochachka 1991), and the rate of protein synthesis (e.g. Morris \& Clarke 1987). Because larvae are generally small and swim slowly, the movement of their propulsive structures (cilia, setae, etc.) and whole body occurs in an environment of low Reynolds numbers $(R e<1)$ where inertia is virtually absent and viscous forces of the surrounding water exert a predominant 
influence (Emlet \& Strathmann 1985, Power 1989, Denny 1990, Emlet 1991). The viscosity of water is determined primarily by its temperature; a reduction in temperature from 25 to $15^{\circ} \mathrm{C}$, for example, results in a $21 \%$ increase in the dynamic viscosity (from here on referred to as 'viscosity') of sea water from 0.0094 to $0.0119 \mathrm{~Pa}$ s. Consequently, temperature-induced changes in viscosity will have a substantial effect on the magnitude of viscous drag operating on larval locomotion. Despite this, the influence of temperatureinduced changes in water viscosity on larval locomotion has received little experimental investigation.

In the only empirical investigation on the influence of viscosity on larval swimming velocity, Podolsky \& Emlet (1993) partitioned the physiological and viscosity-induced effects of temperature on swimming velocity and ciliary water movement of Dendraster excentricus larvae. They reported that over a $10^{\circ} \mathrm{C}$ drop in temperature, viscosity alone accounted for $16 \%$ of the total decline in swimming velocity, and a $55 \%$ decline in ciliary water movement. Clearly then, temperatureinduced changes in water viscosity can have a significant effect on larval swimming velocity. However, the relative effect of temperature-induced changes in water viscosity on larval swimming velocity may not be equal for the larvae of all species and may change over the course of larval development in some species.

Drag increases with increasing velocity and viscosity for any given shape. However, this relationship is not simple: as $R e$ increases, the influence of viscosity on drag declines and inertia (and pressure drag) becomes increasingly important (Vogel 1981). Larvae of many marine invertebrate species undergo considerable growth and development in the plankton which is generally (though not always) associated with an increase in propulsive power and swimming velocity. While the propulsive structures of most larvae move at low $R e$ throughout development, the $R e$ of the larval body may approach and often exceed unity (i.e. $R e \geq 1$ ). As $R e$ increases beyond unity, inertial forces begin to predominate, and the relative importance of viscosityinduced drag declines. Thus the relative influence of water viscosity on swimming velocity will change with larval morphology, size and swimming capacity. Consequently we predict that for species with larvae which exhibit considerable growth and/or increase in swimming velocity, the importance of temperature-induced changes in water viscosity will change over the course of larval development.

Swimming velocity is also only one of a number of larval swimming characteristics that may be influenced by changes in water viscosity. Viscous forces that retard larval swimming velocity will similarly reduce larval sinking velocity. As larvae are negatively buoyant and must swim to maintain their position in the water column (Chia et al. 1984, Emlet \& Strathmann 1985), a reduction in sinking velocity may reduce the energy expenditure required to maintain their position in the water column. We could find no empirical data on the influence of water viscosity on larval sinking velocity in the literature.

We report the results of an experimental investigation in which we used a recently developed protocol to separate the relative physiological and viscosityinduced effects of water temperature (see Podolsky \& Emlet 1993) between 25 and $15^{\circ} \mathrm{C}$ on the swimming and sinking velocities of larvae of the serpulid polychaete Galeolaria caespitosa (L.). To determine whether the relative influence of water viscosity on swimming velocity changed with increasing larval size and swimming velocity, we measured the physiological and viscosity-induced effects of temperature over the course of larval development. Larvae of $G$. caespitosa were used as an experimental model because their size and swimming velocity increase significantly whilst maintaining a trochophore body plan over the course of their planktonic period (Fig. 2 in present study; Marsden \& Anderson 1981). Larvae were tested at $24 \mathrm{~h}$ intervals from hatching to settlement (120 h). Thus, the influence of viscosity upon larval swimming velocity at different development stages was investigated relatively independently of changes in morphology. We used data on the physiological effects of temperature on larval swimming velocity (i.e. separated from the viscosity-induced effects of temperature) to estimate $Q_{10}$ values for the metabolic costs of larval locomotion. We then used these $Q_{10}$ values and data on the effect of water viscosity on larval sinking velocity to compare the metabolic and viscosity-induced effects of water temperature on larval swimming and sinking at 25 and $15^{\circ} \mathrm{C}$.

\section{MATERIALS AND METHODS}

Whole colonies of adult Galeolaria caespitosa were collected from the intertidal zone of pier pilings at Brighton, South Australia, and held at ambient temperatures in a recirculating sea water aquarium system. Gametes were obtained from adults which were removed carefully from their tubes and placed individually in Petri dishes filled with sea water at ambient temperature. Shortly thereafter gametes were released spontaneously into the water. Eggs from 20 females were placed into a $2 \mathrm{l}$ beaker filled with filtered sea water (FSW, $0.22 \mu \mathrm{m}$ ), and approximately $0.5 \mathrm{ml}$ of sperm suspension obtained from 1 male was added. After $10 \mathrm{~min}$, these eggs were filtered through a $53 \mu \mathrm{m}$ screen and transferred to a 11 conical flask containing FSW This flask was aerated gently. As experimental 
treatments (see below) were to be conducted at 15 and $25^{\circ} \mathrm{C}$, larvae were incubated at $20 \pm$ $0.1^{\circ} \mathrm{C}$ in order to minimise thermal shock upon transfer to the treatments. Larvae were fed daily to satiation (i.e. 30 cells $\mu^{-1}$ ) (to ensure that larval growth and development were not food limited) with a 1:1:1 mixture of microalgae Isochrysis galbana, Pavlova lutheri, and Tetraselmis suecica. Algal isolates were obtained from CSIRO (Hobart, Tasmania), and all cultures used were in exponential phase growth.

A small number of larvae were sampled from the culture vessel at $24 \mathrm{~h}$ intervals. These larvae were narcotised in a $7 \%(\mathrm{w} / \mathrm{v})$ $\mathrm{MgCl}_{2}$ solution before preservation in $4 \%$ buffered formalin in FSW. Larval body lengths (i.e. trochosphere lengths; see Fig. 4) of 50 larvae selected randomly from each sample were measured with the aid of a calibrated ocular graticule.

Sinking velocity. Sinking velocity observations were made in FSW in a $5 \mathrm{l}$ glass beaker of $160 \mathrm{~mm}$ diameter (the 'sinking rate chamber') in a thermostatically controlled $\left( \pm 0.1^{\circ} \mathrm{C}\right)$ water bath (Fig. 1). A polyurethane foam sheet ( $30 \mathrm{~mm}$ thick) was fitted to the top of the chamber to eliminate convection currents caused by temperature differentials at the air-water interface. Sinking velocities were measured between 2 pairs of lines located 100 and $200 \mathrm{~mm}$ below the surface (Fig. 1). Lines within each pair were separated by $10 \mathrm{~mm}$ and were drawn around the chamber to permit parallax-free observation of larval depth in the water column. Comparisons of sinking velocities of individual larvae between the lines within each pair allowed us to ensure that sinking velocity was constant throughout the water column and hence was not influenced by convection. Water temperature in the bath and the chamber was monitored electronically with thermocouples with a precision of $\pm 0.1^{\circ} \mathrm{C}$.

The velocities of objects moving at very low Re may be influenced by wall-induced drag ('wall effects'; Winet 1973). Preliminary observations indicated that newly hatched larvae $-80 \mu \mathrm{m}$ long sink at $\sim 0.37 \mathrm{~mm} \mathrm{~s}^{-1}$ and thus at a $R e$ of $\sim 0.03$. Using the equations of White (1946), we calculated that the wall effects on a larva moving at this Re would be negligible if the wall were $\geq 80 \mathrm{~mm}$ distant. Therefore we concluded that wall effects would not substantively influence sinking velocities of larvae in the centre of our sinking rate chamber (160 mm diameter).

We used dead Galeolaria caespitosa larvae to obtain estimates of larval sinking velocities. Samples of larvae were removed from each culture at $24 \mathrm{~h}$ intervals and were killed with a solution of $1 \%$ Formalin $(\mathrm{v} / \mathrm{v})$ in
FSW. Larvae were then rinsed thoroughly with clean FSW before being transferred to FSW in a holding chamber in the water bath. All FSW used was from a single stock solution at $35 \%$. This was important because differences between the salinities of the rinsing, holding and test fluids may otherwise produce differences between the density of fluids in and around the larvae and the water in the sinking rate chamber. Such differences have been observed to influence sinking velocities of larvae (pers obs.).

Measurements of sinking velocities were obtained in a darkened room with the centre of the sinking rate chamber illuminated by light from a fibre-optic light source. Under these conditions the larvae could be seen readily. Larvae were introduced to the centre of the sinking rate chamber through a length of $0.5 \mathrm{~mm}$ catheter tubing attached to a micrometer syringe (AGLA brand, Burrows Wellcome \& Co., London). The micrometer syringe enabled us to introduce individual larvae gently at the surface of the centre of the chamber causing little disruption to the surrounding water. Sinking velocities of larvae were timed between the marked lines to the nearest $0.1 \mathrm{~s}$ with a manual stopwatch.

Sinking velocities were measured for 50 larvae at each of six $24 \mathrm{~h}$ intervals from hatching $(0 \mathrm{~h})$ to the end of the planktonic period (120 h) in FSW at $25^{\circ} \mathrm{C}$ (viscosity $=0.0094 \mathrm{~Pa} \mathrm{~s}$ ) and $15^{\circ} \mathrm{C}$ (viscosity $=0.0119 \mathrm{~Pa} \mathrm{~s}$. Water viscosity was not manipulated independently of temperature as larvae were dead and therefore not physiologically active.

To determine whether larval sinking velocity changed with treatment and development stage, larval sinking velocities for all development stages in the 25 and $15^{\circ} \mathrm{C}$ treatments were compared by 2-way ANOVA at the $5 \%$ significance level. The distribution 


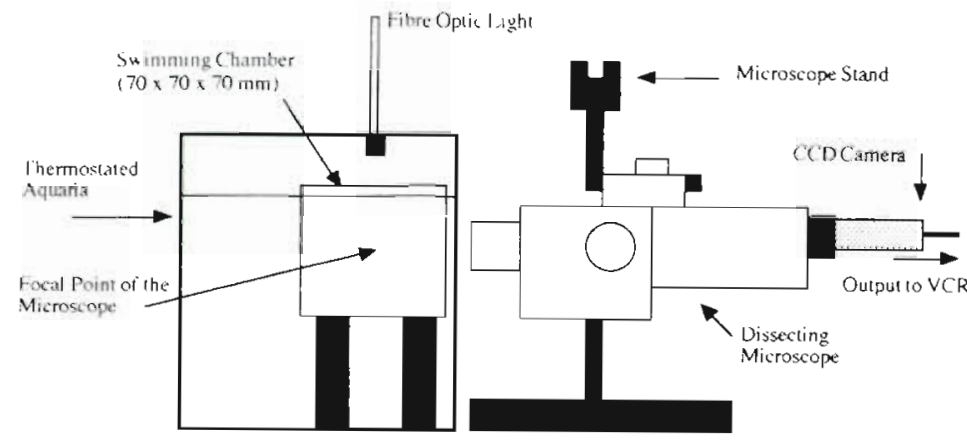

Fig. 2. Experimental set up used to measure the swimming velocities of larvae in treatments. See 'Materials and methods: Swimming velocity' section for details

of the data was normalised and their variances homogenised by square root transformation prior to analyses to conform with the assumptions of the ANOVA (see Zar 1984). To determine where significant differences lay, pairwise post hoc comparisons of means were made with a Tukey's test at the $5 \%$ significance level. The Tukey's test was chosen because it provides a more powerful multiple comparison analysis than alternative procedures (see Zar 1984).

Swimming velocity. Water viscosity was manipulated independently of water temperature by the addition of an inert polymer (Ficoll, Pharmacia Products, provided by Sigma Chemical Co.). A concentration of $1.4 \%$ Ficoll (w/v) in FSW (at 35\%) increased the viscosity of FSW at $25^{\circ} \mathrm{C}(0.0094 \mathrm{~Pa}$ s) to that of FSW at $15^{\circ} \mathrm{C}(0.0119 \mathrm{~Pa} \mathrm{~s})$. Viscosities were measured with a Haake falling ball viscometer (Gilmont Instruments, GV-2100).

Swimming velocities of Galeolaria caespitosa larvae were measured in 4 treatments at each of six 24 h intervals (see above). These treatments were: FSW at $25^{\circ} \mathrm{C}$ (T25); FSW at $15^{\circ} \mathrm{C}$ (T15); FSW at $25^{\circ} \mathrm{C}$ with the viscosity of FSW at $15^{\circ} \mathrm{C}$ (T25 115$)$; and FSW at $25^{\circ} \mathrm{C}$ after larvae had been exposed to the T25 115 treatment for $2 \mathrm{~h}$ (T25C). This final treatment controlled for the possible toxic effects of the Ficoll solution on larval locomotion. The temperatures chosen $\left(15\right.$ and $\left.25^{\circ} \mathrm{C}\right)$ represent the lower and upper limits normally encountered by $G$. caespitosa larvae in South Australia. All FSW used was at a salinity of $35 \%$.

Larval swimming was observed in a purpose-built glass chamber $(70 \times 70 \times 70 \mathrm{~mm})$ (Fig. 2). These dimensions were calculated to minimise any 'wall effects' (Winet 1973) on larvae swimming in the centre of the chamber. As swimming larvae move at a substantially higher velocity than sinking larvae, wall-effects operate over a smaller distance (see Winet 1973) and a smaller chamber could be used in the swimming experiments than in the sinking experiments. How- ever, as in all natural planktonic communities, the close proximity of other individuals in the water column will have influenced the swimming velocities and behaviour of larvae in the swimming chamber.

The swimming chamber was suspended in a thermostatically controlled water bath (Fig. 2). The chamber was filled with $-300 \mathrm{ml}$ of a given treatment solution, and was illuminated from above and below with the aid of a fibre-optic light source. Larvae were acclimated to experimental temperatures for $2 \mathrm{~h}$ prior to introduction to the swimming chambers at a final concentration of -5 larvae $\mathrm{ml}^{-1}$. Video images of larval swimming were recorded through the sides of the chambers with a CCD camera (COHU) mounted on a horizontally positioned stereo-dissecting microscope, which was attached to an S-VHS video recorder (Fig. 2), Recordings were made at 30 frames $\mathrm{s}^{-1}$ and $100 \times$ magnification. This frame rate is in accordance with that used in a previous study on the swimming and sinking velocity of dinoflagellates in which a Motion Analysis system was used in data analysis (Kamykowski et al. 1992). The centre of the field of view and the plane of focus were located in the centre of the chamber. For each treatment an image of a calibrated millimetre grid positioned in the centre of the chamber was recorded on to video tape.

Video tapes of swimming larvae were analysed using a Motion Analysis system (VP-110, Motion Analysis Inc.). This system determines $x, y$ co-ordinates of each larva in successive frames of video, and generates a 'path' for each larva (Fig. 3). After calibration from images of known size (mm grid) and for a known frame rate, the velocity of swimming larvae can be determined. The system is capable of tracking (and discriminating) multiple larvae simultaneously and therefore permits the collection of multiple observations on the individual paths of many larvae in a relatively short time. Swimming velocities were obtained for at least 30 larvae per treatment.

Larvae of all development stages were observed to swim in both helical and linear paths (Fig. 3). To minimise the error caused by taking measurements from sections of the helical swimming paths which were not parallel to the plane of focus of the camera (i.e. larvae swimming toward, or away from, the camera), only the upper $10 \%$ of velocity values from each path were analysed. Preliminary analyses showed that this fraction corresponded to sections of the helical paths which were parallel to the plane of focus of the camera. Mean velocities were then derived for each larva from these values and were estimates of swimming velocities of individual larvae. 


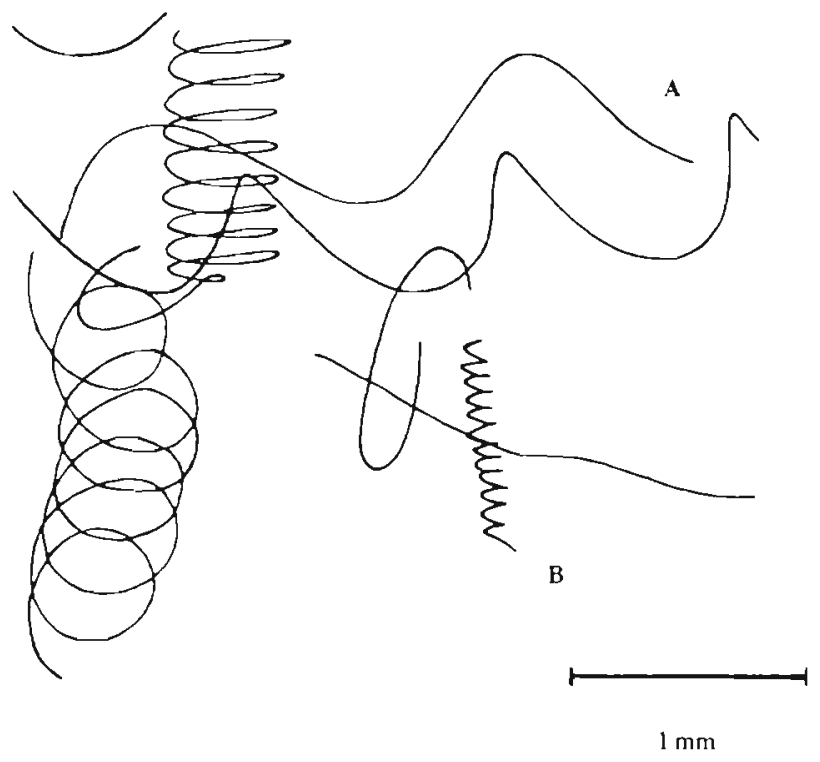

Fig. 3. Galeolaria caespitosa. Computer print out of the swimming paths of larvae tracked on a Motion Analysis system. Larvae swim in both linear (A) and helical (B) swimming paths. To reduce error in estimates of larval swimming velocity caused by larvae swimming toward, or away from, the camera, only the upper $10 \%$ of velocity values for each path were analysed. This fraction approximately corresponded to sections of the helical paths which were parallel to the plane of focus of the camera. See 'Materials and methods: Swimming velocity' section for details

To determine whether larval swimming velocity changed with treatment and development stage, larval swimming velocities for all developmental stages in the treatments T25, T25 15 , and T15 were analysed by 2 -way ANOVA at the $5 \%$ significance level. Data from the control treatment (T25C) were analysed separately against those from the T25 treatment to test for possible toxic effects of Ficoll by 2 -way ANOVA at the $5 \%$ significance level. The distribution of the data was nor-

Table 1 . Galeolaria caespitosa. Swimming velocity at $25^{\circ} \mathrm{C}$, trochosphere length and Reynolds numbers of larvae at 6 development stages 24 h apart. Mean swimming velocities represent the top $10 \%$ of velocity values collected at 30 frames $\mathrm{s}^{-1}$ by a Motion Analysis System (VP 110) from video images of the larvae swimming in water at $25^{\circ} \mathrm{C}$. See Materials and Methods: Swimming velocity' section for details

\begin{tabular}{|ccrc|}
\hline $\begin{array}{c}\text { Larval } \\
\text { development stage } \\
\text { (h post-hatching) }\end{array}$ & $\begin{array}{c}\text { Mean swimming } \\
\text { velocity }\left(\mathrm{mm} \mathrm{s}^{-1}\right) \\
( \pm \mathrm{SE}, \mathrm{n}=30)\end{array}$ & $\begin{array}{c}\text { Mean larval } \\
\text { length }(\mu \mathrm{m}) \\
( \pm \mathrm{SE}, \mathrm{n}=50)\end{array}$ & $R e$ \\
\hline 0 & $2.02 \pm 0.12$ & $88.64 \pm 0.64$ & 0.19 \\
24 & $2.68 \pm 0.16$ & $134.38 \pm 1.61$ & 0.38 \\
48 & $2.62 \pm 0.04$ & $160.90 \pm 1.89$ & 0.46 \\
72 & $3.37 \pm 0.19$ & $190.60 \pm 2.34$ & 0.69 \\
96 & $3.76 \pm 0.13$ & $212.00 \pm 2.37$ & 0.86 \\
120 & $4.27 \pm 0.08$ & $218.60 \pm 2.23$ & 1.11 \\
\hline
\end{tabular}

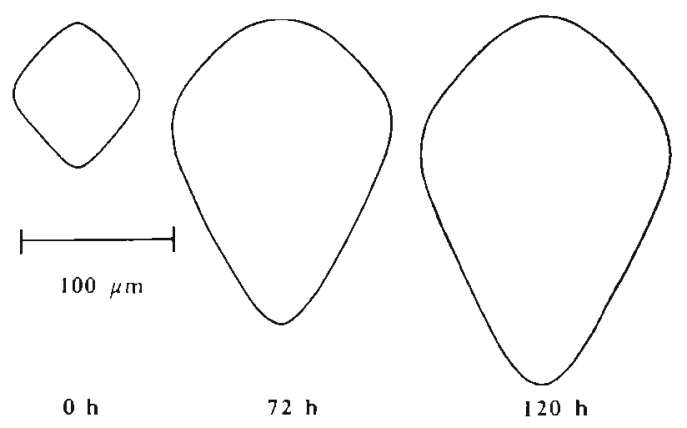

Fig. 4. Galeolaria caespitosa. Trochosphere (larval body) size (mean values; see Table 1 for mean \pm SE larval sizes at each 24 h sampling period) and morphology of larvae at 0 (hatching), 72 and $120 \mathrm{~h}$ post-hatching. Note that trochosphere size increases substantially over the course of the planktonic period but that its morphology does not change significantly (observation made in this study; also see Marsden \& Anderson 1981). Therefore the influence of water viscosity on larval swimming velocity could be determined relatively independently of changes in larval morphology

malised and their variances homogenised by square root transformation prior to analyses to conform with the assumptions of the ANOVA (see Zar 1984). To determine where significant differences lay, pairwise post hoc comparisons of means were made with a Tukey's test at the $5 \%$ significance level.

\section{RESULTS}

\section{Larval growth $\left(20^{\circ} \mathrm{C}\right)$}

Larvae hatched approximately $20 \mathrm{~h}$ after fertilization and were observed to feed readily on all 3 algal species offered. Development was rapid with larvae doubling in length in $48 \mathrm{~h}$. The nectochaete larval stage (see Marsden \& Anderson 1981) was reached at 120 h posthatching and larvae had developed setigers and showed strongly demersal behaviour by $144 \mathrm{~h}$. At this stage larvae were observed to make only brief and slow excursions into the water column. Mean sizes and swimming speeds (at $25^{\circ} \mathrm{C}$ ) of larvae at each stage are shown in Table 1 The morphology of the larval trochosphere did not change substantially from hatching to $120 \mathrm{~h}$ post-hatching (Fig. 4).

A degree of asynchrony in development was present in larval cultures. A small proportion of larvae $(<5 \%)$ developed abnormally. Typically these individuals were small, abnormally shaped and failed to develop beyond 
Table 2. Galeolaria caespitosa. Proportional decline in swimming and sinking velocities of larvae with a $10^{\circ} \mathrm{C}$ reduction in water temperature from 25 to $15^{\circ} \mathrm{C}$ attributable to the combined and separated physiological and viscosity-induced components of reduced temperature. Note that only the viscosity-induced component of temperature is relevant to sinking velocity because the larvae were dead and therefore not physiologically active

\begin{tabular}{|ccccc|}
\hline $\begin{array}{c}\text { Larval } \\
\text { development stage } \\
\text { (h post-hatching) }\end{array}$ & $\begin{array}{c}\text { Decline (\%) in swimming velocity due to: } \\
\text { Combined physiological } \\
\text { and viscosity-induced effects }\end{array}$ & $\begin{array}{c}\text { Physiological } \\
\text { effects }\end{array}$ & $\begin{array}{c}\text { Decline }(\%) \text { in sinking } \\
\text { velocity due to viscosity- } \\
\text { induced effects }\end{array}$ \\
0 & 60.4 & 29.4 & 31 & 26 \\
24 & 52.7 & 27.7 & 25 & 24 \\
78 & 47.8 & 25.8 & 22 & 26 \\
96 & 48.1 & 25.3 & 22.8 & 31.5 \\
120 & 49.7 & 32.7 & 17 & 24.5 \\
Mean \pm SE & 39.7 & 22.4 & 22.5 & 25.5 \\
\hline
\end{tabular}

the early trochophore stage. These individuals were removed from cultures using a pipette and were excluded from all measurements.

\section{Sinking velocity}

Larval sinking velocity increased throughout development and was inversely proportional to the increase in water viscosity which accompanied the temperature drop from 25 to $15^{\circ} \mathrm{C}$ (Fig, 5). Larval sinking velocity at $15^{\circ} \mathrm{C}$ was approximately $26 \%$ slower than at $25^{\circ} \mathrm{C}$ (mean reduction in sinking velocity over all development stages; Table 2). The corresponding increase in viscosity between these two temperatures is $20.6 \%$. Two-way ANOVA showed a significant effect of both development stage $(F=3725.28, \mathrm{p}<0.001)$ and water viscosity $(F=1684.0, \mathrm{p}<0.001)$ on sinking velocity (Table 3). Tukey's test showed that significant differences existed between sinking velocities at 15 and $25^{\circ} \mathrm{C}$ at all development stages (at all development stages $\left.q_{\text {calc }}=0.00, q_{566.11}=4.55, p<0.05\right)$.

\section{Swimming velocity}

Larval swimming velocity increased throughout development, but decreased with both reduced temperature and increased viscosity for all development stages (Fig. 6). Mean swimming velocity at $15^{\circ} \mathrm{C}$ was approximately $49 \%$ lower than at $25^{\circ} \mathrm{C}$ for all developmental stages combined (Table 2). Comparison of swimming velocities in the T25 and T25 15 treatments showed that viscosity alone accounted for approximately $22 \%$ of this decline (mean reduction in sinking velocity over all development stages; Table 2), i.e. approximately half of the decline in swimming velocity observed between the T25 and T15 treatments was attributable to the effects of increased water viscosity. The remainder of this decline is presumed to be due to the physiological effects of reduced temperature on larval swimming velocity.

Two-way ANOVA on swimming velocities in the T25, T25 15 and T15 treatments showed significant

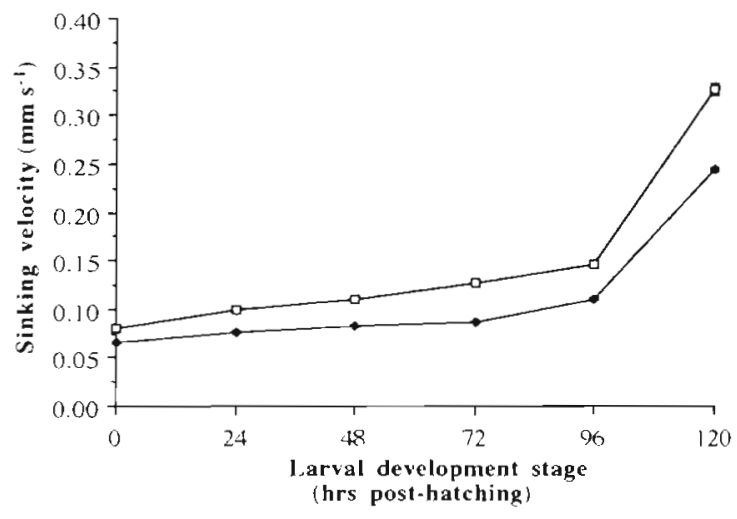

Fig. 5. Galeolaria caespitosa. Sinking velocities (mean $\pm \mathrm{SE}, \mathrm{n}$ $=50$ ) of dead larvae at 6 development stages in water at 25 ( $\square$ ) and $15^{\circ} \mathrm{C}(\bullet)$

Table 3. Caleolaria caespitosa. Two-way analysis of varlance on sinking velocity of dead larvae in water at 25 and $15^{\circ} \mathrm{C}$ at 6 development stages $24 \mathrm{~h}$ apart. See 'Materials and methods: Sinking velocity' section for further details

\begin{tabular}{|lrrrrrr}
\hline $\begin{array}{l}\text { Source of } \\
\text { variation }\end{array}$ & $\begin{array}{c}\text { Sum of } \\
\text { squares }\end{array}$ & df & $\begin{array}{c}\text { Mean } \\
\text { square }\end{array}$ & $F$ & $p$ \\
Within+Residual & 0.14 & 588 & 0.00 & & \\
Development (D) & 4.33 & 5 & 0.87 & 3725.28 & 0.000 \\
Treatment (T) & 0.39 & 1 & 0.39 & 1684.37 & 0.000 \\
D $\times$ T & 0.03 & 5 & 0.01 & 29.46 & 0.000 \\
Model & 4.75 & 11 & 0.43 & 1859.82 & 0.000 \\
Total & 4.89 & 599 & 0.01 & & \\
& & & & & \\
\hline
\end{tabular}


effects of both treatment $(F=217.17, \mathrm{p}<$ $0.0001)$ and developmental stage $(F=114.29$, p $<0.0001$; Table 4). Tukey's test showed that there were significant differences between treatments at all developmental stages except T25 15 and T15 at hatching $\left(q_{\text {calc }}=4.34, q_{5 b 6,11}\right.$ $=4.55, \mathrm{p}>0.05)$. The smallest significant dif ference existed between T25 and T25 15 at hatching $\left(q_{\text {calc }}=4.94, q_{5 \hbar \hbar, 11}=4.55, \mathrm{p}<0.05\right)$. As only 1 non-significant result was found between treatments at 6 development stages, it is reasonable to conclude that the treatments had a significant influence on the swimming velocity of larvae.

Comparison of the distance larvae sank per second with the distance swum in the same period shows that larvae of all development stages would have to expend less than $10 \%$ of their swimming time offsetting sinking (Table 5). However, while sinking velocity is reduced at lower temperatures, the proportion of swimming time expended to offset sinking is greater at 15 than at $25^{\circ} \mathrm{C}$ (paired $t$-test: $t=$ 5.96, $\mathrm{df}=5, \mathrm{p}=0.002$ ).

Reynolds number $(R e)$ of the larvae increased from 0.19 at hatching to 1.11 at $120 \mathrm{~h}$ post-hatching (Table 1). Despite this change, no significant interaction was found between treatment and development stage $(F=0.972, \mathrm{p}>0.05$; Table 4$)$ indicating that the relative effect of viscosity on larval swimming velocity did not change significantly over the course of larval development.

Two-way ANOVA on swimming velocities in the T25 and $\mathrm{T} 25 \mathrm{C}$ treatments showed significant effects of developmental stage $(F=115.25, \mathrm{p}<0.0001)$ but no significant treatment effect $(F=2.68, \mathrm{p}>0.05$; Table 6$)$. This result indicates that Ficoll had no significant influence on larval swimming velocity other than by increasing drag.

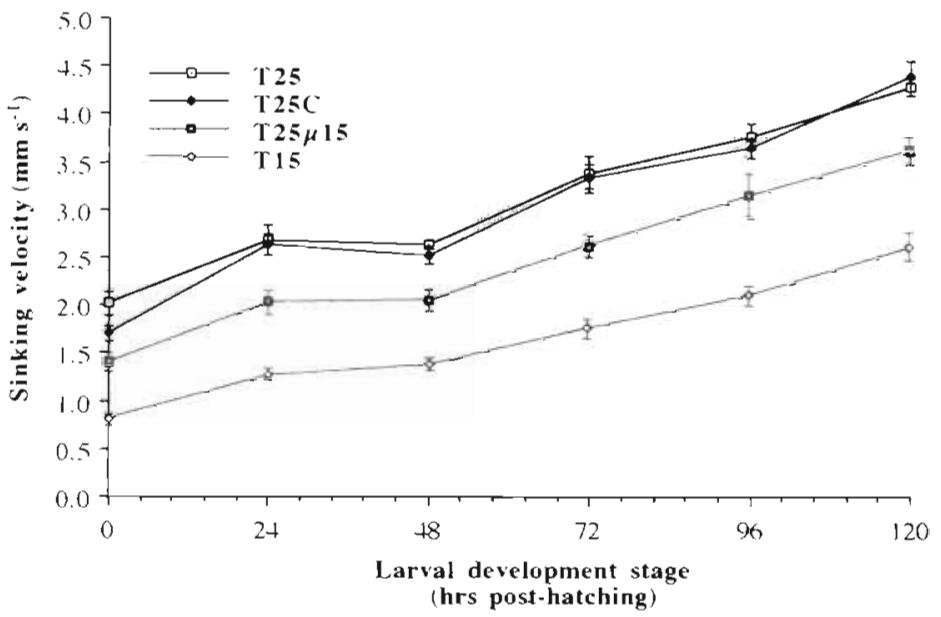

Fig. 6. Galeolaria caespitosa. Swimming velocity (mean $\pm \mathrm{SE}, \mathrm{n}=30$ ) of larvae in 4 treatments: FSW at $25^{\circ} \mathrm{C}$ (T25); FSW at $15^{\circ} \mathrm{C}$ (T15); FSW at $25^{\circ} \mathrm{C}$ with the viscosity of FSW at $15^{\circ} \mathrm{C}(\mathrm{T} 25 \mu 15)$; and FSW at $25^{\circ} \mathrm{C}$ after larvae had been exposed to the T25 15 treatment for $2 \mathrm{~h}$ (T25C). The T25C treatment controlled for the possible toxic effects of the Ficoll solution on larval swimming. See 'Materials and methods: Swimming velocity' section for details

Table 4. Galeolaria caespitosa. Two-way analysis of variance on swimming velocity of larvae in 3 treatments at 6 development stages $24 \mathrm{~h}$ apart. These treatments were: FSW at $25^{\circ} \mathrm{C}$ (T25); FSW at $15^{\circ} \mathrm{C}$ (T15); and FSW at $25^{\circ} \mathrm{C}$ with the viscosity of FSW at $15^{\circ} \mathrm{C}(\mathrm{T} 25 \mu 15)$. See Materials and methods: Swimming velocity' section for further details

\begin{tabular}{|c|c|c|c|c|c|}
\hline $\begin{array}{l}\text { Source of } \\
\text { variation }\end{array}$ & $\begin{array}{l}\text { Sum of } \\
\text { squares }\end{array}$ & $\mathrm{df}$ & $\begin{array}{l}\text { Mean } \\
\text { square }\end{array}$ & $F$ & $\mathrm{p}$ \\
\hline Within+Residual & 64.69 & 834 & 0.08 & & \\
\hline Development (D) & 98.85 & 5 & 79.77 & 116.39 & 0.000 \\
\hline Treatment $(\mathrm{T})$ & 305.01 & 2 & 152.50 & 222.51 & 0.000 \\
\hline $\mathrm{D} \times \mathrm{T}$ & 7.46 & 10 & 0.74 & 1.09 & 0.367 \\
\hline Model & 80.38 & 17 & 4.73 & 60.95 & 0.000 \\
\hline Total & 0.44 & 851 & 0.17 & & \\
\hline
\end{tabular}

Table 5. Galeolaria caespitosa. Proportion of total swimming of larvae required to offset sinking in water at 25 and $15^{\circ} \mathrm{C}$ at 6 development stages $24 \mathrm{~h}$ apart

\begin{tabular}{|c|c|c|c|c|c|c|}
\hline $\begin{array}{l}\text { Larval } \\
\text { development stage } \\
\text { (h post-hatching) }\end{array}$ & $\begin{array}{c}\text { Mean } \\
( \pm \mathrm{SE}, \mathrm{n}=30) \\
\text { swimming } \\
\text { velocity } \\
\left(\mathrm{mm} \mathrm{s}^{-1}\right)\end{array}$ & $\begin{array}{c}25^{\circ} \mathrm{C} \\
\text { Mean } \\
( \pm \mathrm{SE}, \mathrm{n}=50) \\
\text { sinking } \\
\text { velocity } \\
\left(\mathrm{mm} \mathrm{s}^{-1}\right)\end{array}$ & $\begin{array}{l}\text { Proportion of } \\
\text { total swimming } \\
\text { required } \\
\text { to offset } \\
\text { sinking }\end{array}$ & $\begin{array}{c}\text { Mean } \\
( \pm \mathrm{SE}, \mathrm{n}=30) \\
\text { swimming } \\
\text { velocity } \\
\left(\mathrm{mm} \mathrm{s}^{-1}\right)\end{array}$ & $\begin{array}{c}15^{\circ} \mathrm{C} \\
\text { Mean } \\
\left( \pm \mathrm{SE}_{1} \mathrm{n}=50\right) \\
\text { sinking } \\
\text { velocity } \\
\left(\mathrm{mm} \mathrm{s}^{-1}\right)\end{array}$ & $\begin{array}{l}\text { Proportion of } \\
\text { total swimming } \\
\text { required } \\
\text { to offset } \\
\text { sinking }\end{array}$ \\
\hline 0 & $2.02 \pm 0.12$ & $0.08 \pm 0.0006$ & 4.0 & $0.80 \pm 0.057$ & $0.06 \pm 0.0004$ & 8.2 \\
\hline 24 & $2.68 \pm 0.16$ & $0.09 \pm 0.0004$ & 3.7 & $1.27 \pm 0.050$ & $0.07 \pm 0.0004$ & 5.9 \\
\hline 48 & $2.62 \pm 0.04$ & $0.11 \pm 0.0004$ & 4.2 & $1.37 \pm 0.070$ & $0.08 \pm 0.0003$ & 6.0 \\
\hline 72 & $3.37 \pm 0.19$ & $0.12 \pm 0.0013$ & 3.7 & $1.75 \pm 0.099$ & $0.08 \pm 0.0002$ & 4.9 \\
\hline 96 & $3.76 \pm 0.13$ & $0.14 \pm 0.0016$ & 3.9 & $2.08 \pm 0.104$ & $0.11 \pm 0.0005$ & 5.3 \\
\hline 120 & $4.27 \pm 0.08$ & $0.32 \pm 0.0072$ & 7.6 & $2.60 \pm 0.136$ & $0.24 \pm 0.0024$ & 9.3 \\
\hline
\end{tabular}


Table 6. Galeolaria caespitosa. Two-way analysis of variance on swimming velocity of larvae at 6 development stages $24 \mathrm{~h}$ apart in 2 treatments. These treatments were: FSW at $25^{\circ} \mathrm{C}$ (T25) and FSW with the viscosity of FSW at $15^{\circ} \mathrm{C}(\mathrm{T} 25 \mathrm{C})$. This analysis was used to determine whether the polymer (Ficoll), used to manipulate water viscosity, had any toxic effect on the swimming velocity of the larvae. See Materials and methods: Swimming velocity' section for further details

\begin{tabular}{|lrrrrc|}
\hline $\begin{array}{l}\text { Source of } \\
\text { variation }\end{array}$ & $\begin{array}{c}\text { Sum of } \\
\text { squares }\end{array}$ & df & $\begin{array}{c}\text { Mean } \\
\text { square }\end{array}$ & $F$ & $\mathrm{p}$ \\
Within+Residual & 30.85 & 562 & 0.05 & & \\
Development (D) & 31.64 & 5 & 6.33 & 115.25 & 0.000 \\
Treatment (T) & 0.15 & 1 & 0.15 & 2.68 & 0.102 \\
D $\times$ T & 0.23 & 5 & 0.05 & 0.85 & 0.516 \\
Model & 34.95 & 11 & 3.18 & 57.88 & 0.000 \\
Total & 64.81 & 573 & 0.11 & & \\
& & & & & \\
\hline
\end{tabular}

\section{DISCUSSION}

\section{Sinking velocity}

The responses of sinking Galeolaria caespitosa larvae to temperature-induced changes in water viscosity were substantial. Decreased temperature caused a decrease in larval sinking velocity which was proportional to the increase in viscosity. Increasing larval age also resulted in faster sinking velocities (Fig. 5). These results are in accordance with our initial expectations.

\section{Swimming velocity}

It is clear that both physiological and viscosityinduced components of water temperature strongly influence the swimming velocity of Galeolaria caespitosa larvae (Fig. 6). Larvae at $15^{\circ} \mathrm{C}$ swam $49 \%$ slower than those at $25^{\circ} \mathrm{C}$ (mean reduction in swimming velocity over all development stages; Table 2). We predicted that this decline in swimming velocity would be due to both the physiological and viscosity-induced effects of temperature. The effect of viscosity (independent of temperature) was determined by comparing larval swimming velocities in the T25 and T25 15 treatments (Fig. 6) while comparison of larval swimming velocities in the T25 15 and $T 15$ treatments gave the impact of the physiological effects of temperature alone. These comparisons showed that on average over all development stages the decline in swimming velocity due to viscosity alone was $22.5 \%$, while that due to the physiological effect of temperature alone was $27 \%$ (Table 2), i.e. viscosity accounted for $46 \%$ of the total temperature-induced decline in swimming velocity. These results are similar to those of Podolsky \& Emlet (1993), who investigated the impact of tem- perature-induced decline in swimming velocity of sand dollar larvae Dendraster excentricus. They found that viscosity accounted for approximately $40 \%$ of the change in swimming velocity between 22 and $12^{\circ} \mathrm{C}$

In the only other comparable study on the effect of viscosity on locomotory velocity at low Re, Mitchell et al. (1991) reported that water viscosity accounted for only $26 \%$ of the decline in swimming velocity of the purple sulphur bacterium Chromatium minus over a $30^{\circ} \mathrm{C}$ temperature drop (from 45 to $15^{\circ} \mathrm{C}$ ). The increase in viscosity over this temperature range is far greater than that in either this study or that of Podolsky \& Emlet (1993), and raises the question of why viscosity seems to play such a relatively minor role in locomotory kinetics of C. minus (26\%) compared to the larvae of Dendraoter excentricus (40\%) and Galeolaria caespitosa (46\%). Podolsky \& Emlet (1993) note that the rate of change of viscosity with temperatures above $25^{\circ} \mathrm{C}$ is not as great as that below $25^{\circ} \mathrm{C}$ and suggest that this may explain some of the discrepancy between their results and those of Mitchell et al. (1991). Whilst this is true, we suggest it is more likely that the physiological processes which influence the locomotory rate of $C$. minus were more temperature dependent over this (wide) temperature range than those of the $D$. excentricus and $G$. caespitosa larvae in the relatively restricted temperature ranges of our experiments (this study; Podolsky \& Emlet 1993).

We had predicted that changes in $R e$ due to increases in larval size and swimming velocity with development may alter the relative importance of viscosity to larval swimming velocity. Re of Galeolaria caespitosa increased from 0.19 at hatching to 1.11 after 120 h (Table 1). ANOVA of the effects of temperature, viscosity, and development stage on swimming velocity, however, yielded no significant interaction (Table 4). Therefore we must reject our hypothesis in this instance and conclude that the effects of temperature-induced changes in viscosity are probably constant for all larvae of similar size and swimming velocity to those of $G$. caespitosa. Nonetheless, many species of marine invertebrate have larvae which develop from very small eggs to a large size before metamorphosis, and therefore similar studies on different taxa may yield different conclusions. We suggest that future investigations be directed toward determining the relative importance of viscosity to swimming velocity over a wide range of $R e$ (e.g. 1 to 300 )

\section{Potential ecological significance}

Galeolaria caespitosa larvae used in this investigation were cultured in the artificial conditions of a laboratory and it is unknown whether these laboratory cul- 
tured larvae respond to the physiological and viscosity-induced effects of changes in water temperature in the same way as larvae spawned and raised under natural conditions. Therefore, we acknowledge that caution is required in extrapolating the results obtained in this study to larvae in the natural environment. Recognising this limitation, data obtained here and elsewhere (Podolsky \& Emlet 1993) suggest that changes in larval swimming velocity as a result of temperatureinduced changes in water viscosity may be pervasive throughout the marine environment. A viscosityinduced reduction in swimming velocity may increase the time and/or energy required for a larva to acquire food or reach the settlement substrate at low temperatures. As a result, larval growth, development and survivorship may be compromised independently of the direct effects of temperature on physiological processes and development rate.

We had suggested that the increased viscosity of sea water at lower temperatures may reduce the sinking velocity of larvae to the extent that the metabolic costs of swimming to counteract this sinking would be lower at low temperatures. Comparison of swimming and sinking velocities showed that larvae spent $6.6 \%$ of their swimming time offsetting sinking at $15^{\circ} \mathrm{C}$ whereas larvae at $25^{\circ} \mathrm{C}$ only spent $4.5 \%$ of their swimming time in this way (arcsine transformed means of data for all development stages; Table 5). This difference was shown to be statistically significant by paired $t$-test at the $5 \%$ significance level. Thus, larvae at the lower temperature spent $1.4 \times$ more time swimming to retain their location in the water column.

By comparing the swimming velocities of larvae in the T25 15 and the T15 treatments we ascertained the physiological effects of temperature on swimming velocity independently of the viscosity-induced effects. If we next assume that these swimming velocities are a direct (and linear) function of metabolic rate then we can estimate a rate constant $Q_{10}$ for the metabolic costs of larval swimming: $Q_{10}=1.61 \pm 0.085$ (mean $Q_{10}$ for all development stages; data in Fig. 4). We recognise that such estimates may be confounded by other physiological factors (e.g. the efficiency of enzyme function may be altered with a change in temperature; see HoeghGuldberg \& Pearse 1995) and that they clearly need to be confirmed by direct measurements of larval respiration in these treatments. Further, we are also assuming that power requirements increase linearly with swimming velocity and that the mechanical efficiency of cilia is independent of velocity. We can find no theoretical and empirical data in the literature to support or refute these assumptions and their validity can only be addressed by further independent investigation. Acknowledging these assumptions, this estimate suggests that (on average) a rise in temperature from 15 to $25^{\circ} \mathrm{C}$ elicited a 1.6 -fold increase in metabolic activity (as reflected in larval swimming velocity). Consequently, while larvae at $15^{\circ} \mathrm{C}$ spent $1.4 \times$ more time (than larvae at $25^{\circ} \mathrm{C}$ ) to offset sinking, their metabolic costs were only $0.69(1 / 1.6)$ as great. The product of these coefficients is 0.97 . Therefore we suggest that the metabolic costs of swimming to counteract the effects of gravity were similar at both temperatures

Applying this same rationale to larval swimming velocities in sea water suggests that the metabolic costs of swimming at $15^{\circ} \mathrm{C}$ (at $57 \%$ of the velocity and $69 \%$ of the metabolic rate of larvae at $25^{\circ} \mathrm{C}$; see above) would be $1.2 \times$ greater (per unit distance travelled) than at $25^{\circ} \mathrm{C}$. Consequently, while the metabolic costs of retaining location in the water column may be similar at 15 and $25^{\circ} \mathrm{C}$, the costs of locomotion may be slightly higher in colder water.

These estimates may have implications for the development and growth of larvae during colder times of the year. For such larvae, not only may development times be extended (Hoegh-Guldberg \& Pearse 1995), but the metabolic costs of swimming may also be greater (see above)

\section{Conclusions}

These results provide the first estimates of the effect of temperature-induced changes in water viscosity on larval swimming and sinking velocity. These estimates are relevant for any larva at $R e \leq 1$; however many marine invertebrate larvae swim at $R e>1$, where the relationship between viscous and inertial forces has not been fully explored. Given that the relative impact of viscosity on swimming velocity may be vastly different for larvae swimming at different Res, further investigation is clearly warranted. The incorporation of respiration measurements into future investigations would assist greatly in determining the true effects of temperature change on the swimming energetics (i.e. metabolic costs) of marine invertebrate larvae.

Acknowledgements. This research was supported by an ARC grant to J.N.H.

\section{LITERATURE CITED}

Chia FS, Buckland-Nicks J, Young CM (1984) Locomotion of marine invertebrate larvae: a review. Can J Zool 62 $1205-1222$

Clarke A (1983) Life in cold water: the physıological ecology of polar marine ectotherms. Oceanogr Mar Biol Annu Rev 21:341-453

Denny MW (1990) Terrestrial versus aquatic biology: the medium and its message. Am Zool 30:111-121

Emlet RB (1991) Functional constraints on the evolution of larval forms of marine invertebrates: experimental and com- 
parative evidence. Am Zool 31:707-725

Emtet RB, Strathmann RR (1985) Gravity, drag and feeding currents of small zooplankton. Science 22:1016-1017

Hirche HJ (1984) Temperature and metabolism of planktonI. Respiration of Antarctic zooplankton at different temperatures with a comparison of Antarctic and Nordic krill. Comp Biochem Physiol 77 A: 361-368

Hochachka PW (1991) Temperature: the ectothermy option. In: Hochachka PW, Mommensen TP (eds) Biochemistry and molecular biology of fishes, Vol 1 Elsevier Science Publ BV, Amsterdam, p 313-322

Hoegh-Guldberg O, Pearse JS (1995) Temperature, food availdbility and the development of marine invertebrate larvae. Am Zool 35:415-425

Kamykowski D, Reed RE, Kirkpatrick GJ (1992) Comparison of sinking velocity, swimming velocity, rotation and path characteristics among six marine dinoflagellate species. Mar Biol 113:319-328

Marsden JR, Anderson DT (1981) Larval development and metamorphosis of the serpulid polychaete Galeolaria caespitosa Lamarck. Aust J Mar Freshwat Res 32:667-680

Mitchell JG, Martinez-Alonzo M, Lalucat J, Esteve I, Brown S (1991) Velocity changes, long runs and reversals in the

Editorial responsibility: Otto Kinne (Editor).

Oldendorf/Luhe, Germany
Chromatium minus swimming response. J Bacteriol 173: 997-1003

Morris GJ. Clarke A (1997) Cells at low temperatures. In: Grout BWW, Morris GJ (eds) The effects of low temperature on biological systems. Edward Arnold, London. p 72-119

Podolsky RD, Emlet RB (1993) Separating the effects of temperature and viscosity on swimming and water movement by sand dollar larvae (Dendraster excentricus). J Exp Biol 176:207-221

Power JH (1989) Sink or swimi growth dynamics and zooplankton hydromechanics. Am Nat 133(5):706-721

Robinson C, Williams PJleB (1993) Temperature and Antarctic plankton community respiration. J Plankton Res 15: $1035-1051$

Vogel S (1981) Life in moving fluids. Willard Grant Press, Boston, Princeton University Press, Princeton, NJ

White CM (1946) The drag of cylinders in fluids at low speeds Proc R Soc Lond A 186:472-479

Winet $H$ (1973) Wall drag on free-moving ciliated microorganisms. J Exp Biol 59:753-766

Zar JH (1984) Biostatistical analysis, 2nd edn. Prentice-Hall, Englewood Cliffs, NJ

Submitted: February 13, 1996; Accepted: October 1, 1997 Proofs received from author(s): November 10, 1997 